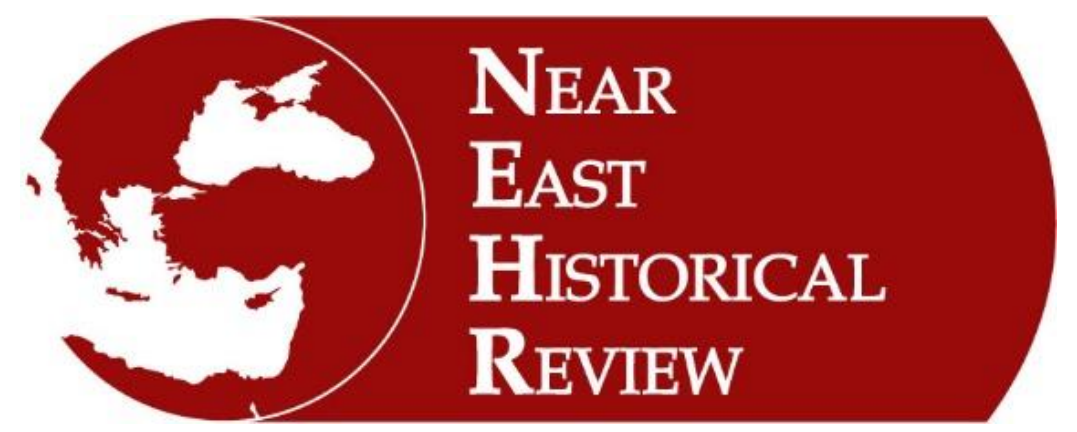

\title{
TURKISH (OTTOMAN) SOURCES FOR THE HISTORY OF MONTENEGRO
}

Karadağ Tarihi İçin Türk (Osmanlı) Kaynakları

\author{
Šerbo Rastoder \\ Prof. Dr., Montenegro University, Montenegro \\ e-mail: serbor@t-com.me \\ ORCID ID: 0000-0001-9328-2550
}

\author{
Near East Historical Review \\ $11 / 1$, January / Ocak 2021 \\ e-ISSN: 2717-6363 (Online) \\ www.nehrreview.com
}

\footnotetext{
Article Type - Makale Türü : Research Article / Araştırma Makalesi Received Date - Geliş Tarihi : 11.10 .2020

Accepted Date - Kabul Tarihi : 20.12.2021

Pages-Sayfa : $17-26$

doi : http://dx.doi.org/10.29228/nehrreview. 48711
}

Citation-Attf : Šerbo Rastoder, "Turkish (Ottoman) Sources for the History of Montenegro", Near East Historical Review, 11/1, January, 2021, pp. $17-26$ 



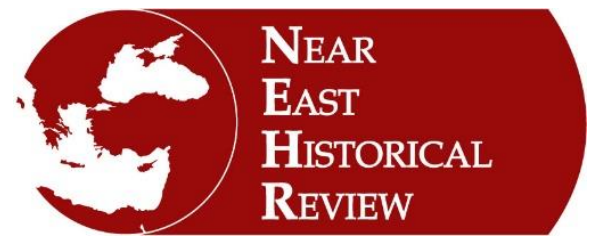

Near $\boldsymbol{E}$ ast $\boldsymbol{H}$ istorical Review

11/1, January - Ocak 2021

$17-26$

Research Article - Araştırma Makalesi

\title{
TURKISH (OTTOMAN) SOURCES FOR THE HISTORY OF MONTENEGRO
}

\author{
Karadă̆ Tarihi İçin Türk (Osmanlı) Kaynakları
}

\author{
Šerbo Rastoder \\ Prof. Dr., Montenegro University, Montenegro \\ e-mail: serbor@t-com.me \\ ORCID ID: 0000-0001-9328-2550
}

\begin{abstract}
As soon as, it is estimated there are about 60.000 documents in the Turkish archives referring to Montenegro. The study aims on the importance for the Ottoman Empire sources for the history of Montenegro. The aim of the study is to reveal the importance of Ottoman archive documents for the history of Montenegro.
\end{abstract}

Keywords: Historiography, Montenegro history, Ottoman Empire archives, Ottoman Empire history
$\ddot{O ̈ z}$

Türk arşivlerinde Karadağ'a atıfta bulunan yaklaşık 60.000 belge olduğu tahmin edilmektedir. $\mathrm{Bu}$ çalışma, Karadağ tarihi için Osmanlı kaynaklarının önemine odaklanmıştır. Çalışmanın amacı, Osmanlı arşiv belgelerinin Karadağ tarihi açısından önemini ortaya koymaktır.

Anahtar Kelimeler: Karadağ Tarihi, Osmanlı arşivleri, Osmanlı tarihi, tarih yazımı

\section{Introduction}

For the first few years of its activities, the National Academies have already recognised the work on the edition of historic resources as a scientific priority. In that sense, the Montenegrin Academy of Science and Art is an exception, only in the area, in which that kind of work was more individual activity of some members than it has been a collective and coordinated action. The reason for that is the possible primacy of sources of domestic provenance, which is considered a usual scientific standard. The results of that work are recognizable through numerous works of collections of historic sources, published under the National Academy. In the late '80s of the 20th century, the academic community began thinking about achievements and contents done, and the necessity of further involvement in that sense. It was noticed immediately that the academic scientific community had only just started of using historical sources of "foreign" origin, i.e. that historical sources were stored in the institutions of countries ${ }^{1}$ with which Montenegro had intense relationships throughout the history, and important not only for the additional historic research. Their lack of knowledge represents a serious disability for the development of historical science in general, and of the historiography of Montenegro in particular.

\footnotetext{
${ }^{1}$ Uğur Özcan, II. Abdülhamid Dönemi Osmanlı Karadağ Siyasi İlişkileri, Türk Tarih Kurumu , Ankara 2013.
} 
The rich archives of some countries (Russia, France, Italy, Austria, Great Britain, Germany and the United States) were used as the cognitive basis for numerous, valuable, and important historiography accomplishments. The researchers have been typically fascinated by the knowledge about the number of these sources, bearing always in mind the geographic and demographic size of Montenegro. In addition, it is evident that the largest part of "foreign" sources was placed chronologically in the 19th and 20th century, i.e.in the modern era, while the earlier periods of history in a heuristic sense, were mainly the exposure derived from the sources of "domestic" provenance. From the point of view of the scientific requirements and methodology of historical research, the mentioned practise was justified by "the lack" of another type of sources of provenance, which has proven to be an unfounded perspective that is not derived from knowledge but only for justifications. The first procedures in this context have already shown that organized and continuous work on the research of sources of "foreign" provenance not only has a complete scientific sense, but also necessarily requires a verification of limits of existing knowledge.

\section{The Montenegrin Historiographic and Ottoman Sources}

The Montenegrin historiographic tradition in its heritage fosters different methodological discourses from romanticism to modernism. In the fluctuation between the modern and the traditional, it is hard to recognise boundaries where one ends, and the other begins or where it is possible to recognise the dominance and the need of science, which is not an utilitarian projection of romanticism.

18

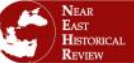

11 / 1

January 2021

The study of Ottoman historical and cultural heritage in this region implied the need for desirable production of stereotypes, which served to strengthen self-awareness and desired selfimage in time of national-romanticism of $19^{\text {th }}$ century. It means that displaying of " the other" implied the mandatory "negative" attribute and demonization in order to finally build up desirable historical consciousness. The complexity of the issue arises from the fact that the story of the "other" one is always the story about the one with who you have been in direct or indirect contact. In this particular case, when it comes to Ottomans, as the "other" one, then the place of "encounter" is recognised as "battlefield" in historiography which becomes the key point of narration, inspiration and research. Within six centuries of direct contact of the Ottomans and Montenegrins, the main part of historiographical heritage-protected the "warrior history" and its related events, which ultimately resulted in the need to keep all other aspects from culture to mental archaeology in the background, counting importance and content more relevant and complex than battle and battlefield. Such an approach to understanding of history produced numerous stereotypes and myths that have survived until today. Besides historiography, there were other branches of science that helped from literature (especially epic) to other forms of creativity. Of course, this is not a matter of value judgment derived from concrete insights and undeniable evidence, which is a legitimate scientific method, but a form used as something a priori, proven and indisputable. In this context, it should be noted that this is not Montenegrin specificity, but it is a common phenomenon in almost all Balkan national historiographic traditions in which the "other" one is, by definition, interpreted in the negative context, especially in the case of an encounter with that "other" on the battlefield. ${ }^{2}$ It is not a coincidence that modern critic of historiography in this area was based on issues related to the dominance of the Ottomans ${ }^{3}$ and questioning the myths related to the awareness of it. More precisely, the basis of historical knowledge is made of the historical source. They cause the quality and the content of the historical exposition because what has been is unchanged, we could know what has happened only if we

\footnotetext{
2 for problem of others in Montenegro see Abidin Temizer, "Karadağ'da öteki sorunu: Müslümanlar (1878-1913)", History Studies, Volume 5 Issue 3, May 2013, p. 223-240,

${ }^{3}$ Abidin Temizer, "Karadağ'da Osmanlı Hâkimiyetine Dair”, Yeni Türkiye Yeni Türkiye, Rumeli-Balkanlar Özel Saylst-III, 2015, p.3016-3015.
} 
have a testimony about it. Therefore, it is important to determine whether there is or was a scientific strategy, which would eliminate this limit? There is no history of science without the historical sources, i.e. stories about the past. More precisely, if there are no sources, there is no history (prehistory).It is also clear that the sources themselves are not the history, nor the mere existence of sources is enough for knowledge and research of the past. On the other hand, the historian makes a selection of the facts contained in the historical source. The historian would never make any judgement, if he waited to collect all historical sources or to describe all facts included therein. The essence of scientific opinion is in the selection of historical sources. Where would a historian arrive if he would describe every historical source every day or the period he is studying? For the study of Montenegrin history, so-called "foreign" sources have a particular importance: Vatican, Venetian, Austro-Hungarian, Russian, and Turkish sources. From this group of "foreign" sources, we could say that sources of Turkish (Ottoman) provenance were the least studied, known and used. In his work "Foreign sources on the history of Montenegro", the academic Dimitrije Dimo Vujović rightfully saw that it is impossible to study the history of Montenegro from $16^{\text {th }}$ to $19^{\text {th }}$ century without the knowledge of Turkish sources ${ }^{4}$. Hence, the logical question: Why are sources of "Ottomans" or Turkish provenance least represented in the Montenegrin historiography in relation to other foreign sources? The answer to this complex question we can find in the following facts: 1. Istanbul archive was opened in 1936 for scientific work. 2. This type of sources requires a special profile of experts that Montenegro mostly did not have. More specifically, the first initiatives of organised research materials from the archives of Ottoman recorded on November 11, 1927; on March 20, 1928; on February 4, 1929, and on December 30, 1930 when the Serbian Royal Academy (SRA), through Ministry of foreign affairs of Kingdom of Serbs, Croats, and Slovenes (KSCS), launched initiatives to send an expert commission to copy significant documents from the Turkish archives about "Serbian history" . At the same time, there was been an initiative of collecting of archival materials about Muslims in the area of The Kingdom of SCS, by Franco Babinger, the university professor in Berlin, who had been regularly visiting Yugoslavia since 1927. In cooperation with the YASA (Yugoslav Academy of Sciences and Arts in Zagreb) and professor Gavro Manojlović, Babinger collected around 800 Turkish, Arabic and Persian manuscripts. Then he also engaged the Russian emigrant A. A. Olesijski, so with his work this collection reached the number of 1,200 copies, which after cataloguing became the largest systematised catalogue of Turkish documents in Europe. At the same time, that was the basis on which Franc Babinger offered the cooperation to the SRA. To this initiative SRA responded with a new request (in March of 1931) to The Ministry of foreign affairs to enable sending of an expert commission to Istanbul. At the session of the SRA Presidency, attended by the president and secretary of the SRA Bogdan Gavrilović and Aleksandar Belić, members: Nikola Vulić, Uros Predic, Jovan Radonić, Vladimir K. Petrovic, Slobodan Jovanovic, Stanoje Stanojevic, and an associate member Vladimir Ćorović , and was discussed of the necessity of the collecting of "turkish manuscripts of history, literature and other disciplines". A Committee for the collection and publication was founded of "Turkish archives about Serbian history (Jovan Radonić, Stanoje Stanojevic, Jovan N.Tomic, Vladimir Ćorović. ${ }^{6}$

Rumours and inscriptions about the sales of valuable documents from the Ottoman archives as an old paper to the Bulgarians, as well as rumours that " the Government in Ankara is planning to destroy the Ottoman archives "7, which were later established as false, had been additionally

\footnotetext{
${ }^{4}$ See: Dimitrije Dimo Vujovic, "Foreign Sources on the History of Montenegro, Sources and historiography about Montenegro", Works from a Scientific Meeting Held in Titograd 17-18 December 1990, CANU 13, 1993, 127-145

5 About this writes substantially “О проблемима истраживања југословенских стручних делегација у архивима Беча и Цариграда “, (On Professional Delegations' Research Problems in Vienna and Constantinople Archives), АРХИВ Часопис Архива Југославије (ARCHIVE Journal of the Archives of Yugoslavia), 2012, vol. 1-2, p.34-49. ${ }^{6}$ Ibid.

${ }^{7}$ Ibid, p. 36.
} 
motivated and encouraged scientific institutions in the Yugoslav country at the time to put pressure through diplomatic channels in order to start with the research. At the same time, there were attempts to do something and with "personal connections", and it was not until the end of 1931 that a budget for the work of the Committee for the collection and publication of Turkish archives had been approved. Sub-committees were formed in Sarajevo and Skopje. The organisation of work in the field was entrusted to John Radoniću and Gliši Elezoviću in Macedonia, the State Archives in Dubrovnik and the Director of the National Museum in Sarajevo Vladimir Skariću in Bosnia. At the time, collaborators on the translation of the archives and manuscripts were hired: Nedžib Abdurahmanovic, Mehmed Spaho and Tyrone, and the work of the Committee was extended for gathering archives from Bulgaria. In any event, it had not been possible to start the research in Istanbul for a long time. In 1935, "Turkish Commission for the Registration and Collection of documents in Istanbul was established and headed by the German Professor Ritter. It was then envisaged that all written material in Arabic, Persian and Turkish to be transferred to the Library Sulejmani. According to the estimates of around 70.000 documents and manuscripts, approximately 21.000 were related to the Balkans. It was not until 1936 (February 27) that "the Turkish Government had made a principled decision to allow the examination of documents older than $1878 .^{8}$ By the mid-April of 1936, all the necessary authorisations for the residence and work of the experts were obtained ( Stanoje Stanojević, Fehim Bajraktarević), as well as for taking photos of certain documents from the museum collections in Istanbul. Gliša Elezović, who was formally appointed as an officer in the Consulate in Istanbul, joined the team later on. In February 1937, the Military Museum in Istanbul donated to the Military Museum in Belgrade a collection of items. On March 30, 1938, the MFA of the KY (Ministry of Foreign Affairs of the Kingdom of Yugoslavia) donated to the Ministry of Education of Turkey facsimiles of Turkish documents kept in the SKA Archive and State Archive in Dubrovnik.

Montenegro, then as part of the Yugoslav State was not the focus of attention, nor able to initiate, and especially, to organize similar research. In this context, something like that did not recognise as a priority not even in the second half of 20th century, when its first scientific and professional organisations were established. Nevertheless, as a part of the unified Balkan and Yugoslav area, it could not remain out of the presence and mention in Ottoman documents. This meant that certain improvements made in this area need to be valorised.

Improvements made in publishing historical sources and that, above all, thanks to the experts from the region, such as Branislav Đurđev, Hazim Šabanović, Hamid Hadžibegić, Lamija Hadžiosmanović, Milan Vasić, Ahmed Aličić, Nedim Filipović, Dušanka Bojanić, Olga Zirojević and others, constitute the basis for further research. Mainly thanks to them, defteri were published as the most important, and often the only sources of the 15th and 16th century. This type of Turkish (Ottoman) sources is of particular significance for the social history. As such, they provide a wealth of relevant information relevant for social, demographic and political analysis. Hence, it is important to know that in Turkish archives: "T.C. Cumhurbaşkanlığı Devlet Arşivleri Başkanlığı Osmanlı Arşivi" (Turkish Presidency State Archives of the Republic of Turkey Department of Ottoman Archives) in Istanbul (BOA) and "Tapu ve Kadastro Genel Müdürlüğü Kuyûd-1 Kadîme Arşivi" (General Directotare of Land Registry and Cadastre "Kuyud-1 Kadime Archives) in Ankara (T.K.A.) preserved, among others, these important documents related to Montenegro:

\footnotetext{
${ }^{8}$ Ibid, 37.
} 
1. Defter of Herzegovina Sandzak of 1477, BOA, TT.d., $5 .^{9}$

2. Detailed and summary list of Shkodra Sandzak of 1485; BOA, TT.d., 17. ${ }^{10}$

3. Defter for Piperi, Kuči, Hoti, Klementi of 1497, BOA, TT.d., 26. ${ }^{11}$

4. List of capitation collected from Montenegro in 1521, BOA, TT.d., 106. ${ }^{12}$

5. List of the Montenegrin Sandzak from 1523, BOA, TT.d., 122. ${ }^{13}$

6. List of Rumelia timar from 1529 to 1536 , BOA, TT.d., 367. ${ }^{14}$

8. Detailer defter for Dukagjini sandzak from 1570, BOA, TT.d., 499. ${ }^{15}$

9. Defter for Shkodër sandzak from 1570, BOA, TT.d., $500^{16}$

10. Detailed list of Dukagjini sandzak from 1591, T.K.A. No.63;

11. List of Grbalj from 1683; List of tsar's hasovi of Niksic (today surroundings of Kolasin), which are listed in the summary section cadastre of "Krajište Isa Bega Isakovic" BOA, № 12 of 1455 , etc.

In fact, most of the documents listed have been already published. If you have in mind the fact that 'the Bibliography on sources for the history of Montenegro" has 9900 bibliographic units, and then it is easy to notice that among them there is no $10 \%$ of (registered) published sources of Turkish (Ottoman) provenance. This information points to the conclusion that there are no sources of "the other party" for more than five centuries of Montenegrin history. In other words, that is, this situation is the basis of the established opinion "that by the 20th century the Balkan history was mostly oral". If today we were able to identify the problem that we have to face, we would have to start from the statement" that the story was created first (narration), and then the need to make a story verifiable (based on a historical source)". The myth was born from the narration which had become the foundation of historical consciousness. That is why the appearance of critical and scientific of historiography in Balkan cultural tradition is an epochal cultural process comparable with the enlightenment tradition in the west. It is worth remembering the intellectual earthquake made by Ilarion Ruvarac (1832-1905), the father of Serbian critical historiography, who jeopardised the historical foundation of Kosovo myth or Montenegro myth (that Montenegro was never under Turkish rule) .

The question of Montenegrin myth was absolved scientifically in the middle of $20^{\text {th }}$ century by publishing the study of B. Đurđa. The scientific foundations of the historical heritage were laid down there, which we can analyze nowadays as qualitative as substantive. In the oldest and leading historical magazine in Montenegro "Zapisima" i.e. "Istorijskim zapisima" from 1927 to

9 "Hersek Livası Nahiyelerinin Nüfus Hasılatıyla Tımarlarına Ve Kale Müstahfızlarına Ait Tımarları Havi Mufassal Tahrir Defteri.", BOA, TT.d., 5, (H-29-12-882).

10 "İşkodra, İpek ve Podgoriçe Vesair Nahiyelerin Nüfus, Hasilat-1 Has, Zeamet Ve Timarlarini Gösterir Mufassal Tahrir Defteri”, BOA, TT.d., 17 (H-29-12-890).

11 İskenderiye Livasina Tabi İpek, Büberler, Klemente, Komnin, Dragoz'a Ait Has, Timar Ve Zeametlerinin Icmal Defteri. BOA, TT.d., 26 (H-29-12-902).

12 “Karadağ Vilayetinin Nüfus Ve Baştinelerini Havi Mufassal Tahrir Defteri”, BOA, TT.d., 106, (H-29-12-927).

13 "Karadağ Vilayetinin Nufus Ve Hasilat Ve Memlahalariyla Kardağ Kanunnamesini Havi Mufassal Tahrir Defteri.", BOA, TT.d., 122 (H-29-12-929).

14 "Karlıili, Tırhala, Ağrıboz, Mora, Rodos, İşkodra, Dukakin, Ohri, İlbasan Livaları Mufassal Tahrir Defteri. y.tt", BOA, TT.d., 367, (H-29-12-973).

15 "Dukakin Livasının ve Karacadağ Nahiyelerinin Nüfuslarını Ve Haslarını Ve Venedik'e Aid Kotur, Astari Grad, Bar Kaleleri Hududlarını Karacadağ Kanunnamesini Ve Dukakin Livasındaki Tımarları Havi Mufassal Tahrir Defteri”, BOA, TT.d., 499 (H-29-12-978).

16 "İskenderiye Livası Kanunnamesiyle İskenderiye Livası Köylerinin Nüfus Ve Hasılatıyla Tımar Ve Evkafını Havi Mufassal Tahrir Defteri.”, BOA, TT.d., 500 (H-29-12-978). 
2007, 5060 contributions were published. The number of contributions related to Turkish history is from 3912 to 3926 or only 14, while the contributions related to Montenegrin-Turkish relations are from 969 to 982 or only 13 , which makes a total of 27 articles or $0,53 \%$. This fact is very interesting phenomenon that the historiography in Montenegro in the communist period (19451989) had a very enviable production with more than 360 books on over 81,000 pages of text, and over 2,500 articles on 36,000 pages. In the "Istorijskim zapisima" in the mentioned period, was published more than 1,600 works on over 22,000 pages, i.e. the total number of the pages on which the Montenegrin history was treated exceeds 117.000 or 2.925 per year on average. The history presented in the thematic and chronologically manner is set mostly in $19^{\text {th }}$ and $20^{\text {th }}$ century. In general, it can be noticed that the major research actions in this area were made in the '50s and '60s of the 20th centuries, but even though that was the period of institutionalization of historical science in Montenegro there was not an organised and scientifically designed research of the Ottoman period of history. That did not happen even after the breakup of the ideological paradigm (1989) and the disintegration of the state. In this turbulent period, which abounded with internal conflicts, from verbal to armed, the historical science served either to prove the justification of the requirements of political elites in their post-communist calculation or as means of the rationalisation of existing conflicts. Consequently, the importance of this scientific discipline has grown disproportionately to its social position and influence. In the methodological sense, the historical science moves from pamphlets, national-romanticism narration to sporadic conceptualisation of problems. The general revalorisation of historiographic heritage shifts its interests from classic and social to ethnic. The great dynamization within the historiography is encouraged by the general processes of transition from one to the other society, as a positive consequence has the fact that all historical themes are open. The territory of Montenegro is characterised by a huge production of historiography in this period from 1989 to 2006.

According to some estimates and the number of titles, it was bigger than any other Balkan states in relation to the number of inhabitants. Many itineraries (especially of foreigners) and memoirs were translated and published, and also numerous reprint editions of old and forgotten books of traditional school were made. It comes to a general revalorisation of historiographic heritage. The "Battle for history."(Fevr) turns into an intellectual conflict over identity in which science is subjected to utilitarianism. The period of the $15^{\text {th }}, 16^{\text {th }}, 17^{\text {th }}$ and partly of the $18^{\text {th }}$ century mostly does not have its own researchers. The reason for this is certainly the fact that the relevant archival materials mostly are in Turkish (Turkish archives) and in Italian, Latin (Venetian, Zadar, Dubrovnik, Vatican archives). However, this does not mean that there is no interest in these periods of history. Truthfully, in the period from 1991 to 2003 only two of 19 scientific conferences were organised, which could thematically be related to the area that interest us. The first was organised the Historical institute of Montenegro and it was titled: "The battle for Montenegro, Martinići - Krusi 1796-1996". The conference was held on October 1 and 2, 1996 in Podgorica, on the occasion of 200 years of famous battles against the Ottoman empire. The second was organized by CANU and the Faculty of Philosophy: "International recognition of Montenegro". A scientific conference was organised by the Historical Institute of Montenegro, CANU and Faculty of Philosophy in Niksic on May 12 and 12, 1998, on the occasion of the jubilee of 140 years of the battle of Grahovac (1858) and 120 years of international recognition of Montenegro. Until the appearance of "Almanac" (1993), there was no institutionalised and organised study of Islamic-oriental heritage in the area of Montenegro. The aforementioned facts were the main motive for the initiation of an organized, systematized and scientifically designed collection, preparation and publication of the historical sources of the Ottoman provenance. In 2015, in CANU (Montenegrin Academy of Arts and Science) as the highest scientific institution in state, the work has started on preparing the edition: "Turkish ((Ottomans) sources for the history of Montenegro". In the first composition of the Operational team there was a group of 20 scientists selected according to the principle of scientific curiosity and competency, generational difference 
and proven reputation in the need of collective and organized work: Prof. Dr. Šerbo Rastoder, CANU, associate member, project manager and operational team: academic Miomir Dašić, academic Đorđe Borozan, Prof. Dr. Nada Tomović, Dr. Dragana Kujović, Prof. Dr Marijan Premović, Mr. Sait Šabotić, Mr. Novak Adżić, Mr. Admir Adrović, Mr. Tomaš Damjanović, Mr. Ajdin Rakić, Mirjana Vukasović, Bajro Agović). In particular, the specificity of the project was the involvement of large number of experts from the Turkish academic community (mainly historians): Prof. Dr. Ilber Ortayli, foreign member of CANU, the writer of introduction of the first books of edition; Prof. Dr. Idris Bostan, Istanbul University; Assoc. Prof. Dr. Abidin Temizer, (Ph.D. in History of Montenegro) Burdur Mehmet Akif Ersoy University, Prof. Dr. Hatice Oruç, (Ph.D. in History of Balkan), Ankara University; Assoc. Prof. Dr. Ugur Ozcan, (PhD in History of Montenegro) Friedrich-Schiller University of Jena, especially those who dealt with the history of Montenegro and South-East Europe. The involvement of experts from the region (Prof. Dr Enes Pelidija, University of Sarajevo, Faculty of Philosophy), bridged the handicap in lack of experience and expert knowledge in the work on similar projects. While involving a larger number of associates of the youngest part of the Montenegrin academic community (postgraduates and young researchers) is motivated by the awareness that it is a long-term scientific project in which younger researchers will gain experience that will enable the continuity of the project in a longer period. The basic methodological principles in the work on preparing the edition have been defined, which can be summarised in several binding principles: Firstly, the need for the additional valorisation of the existing historiographic heritage began. Having awareness about that, it meant that over 200 bibliographic units were identified in terms of publishing historical sources Turkish (Ottoman) provenance important for the history on Montenegro until the beginning of work on the project. The fact that the most of them are disclosed in publications printed outside of Montenegro should not be an obstacle in the need for unification in one place all available published and translated sources important for history of Montenegro. The fact that this principle was accepted conditioned the concept that the first volumes of the edition would be reprinted, collected and translated sources. Secondly, the strict compliance of scientific methodology, obliged us to adopt the chronological principle (time of sources) as the principle of place determination of sources in the edition. Of course, this is mainly about the sources dated by hidra, it also meant the obligation that dating of sources would be marked by the time used at the time of creation and the time of modern user of sources. Thirdly, a dilemma of resolving the principle of provenance set an interesting contradiction perceived in practice, which means, how we could determinate a principle of provenance: by language, territory, institute? Each of these principles also conditioned a different approach to the sources. We chose the one which we consider to be the most comprehensive, useful, and the most demanding, and that is the principle of the alphabet of sources. More precisely, the fact that a document was written in the Ottoman (Turkish) alphabet, as a rule definition meant that it was "unreadable" and thus conditioned the need - if it agrees with the principle of originality, the cognitive value of content and the fact that it refers to the area of (today's) Montenegro to find an adequate place in the edition.

This principle conditioned the need to take into account, all, or at least available sources, stored in domestic (archives in Montenegro) or regional archives (Dubrovnik, Sarajevo, Zagreb, Beograd etc.) and at the same time actualised the challenge: what we could do with an enormous number of sources which satisfy the principle of language and alphabet, and do not belong to the traditional type of sources represented in similar publications? First of all, we mean a large number of sources of Islamic epigraphy (inscriptions and notes on stone) or a huge number of manuscripts (books)that can have a characteristic of the source in the broadest sense, and do not belong to the traditional type of historiographical written sources? The following dilemma is conditioned by the fact that there are many groups of Ottoman sources written in a Cyrilic alphabet. It means also the need to understand this issue and out of the context of rigid 
understanding of the provenance and the satisfying the principles of science as a determining factor. Realising that a vastly unexplored heritage is not a job of only one research team, we started from a less demanding project of the identification of the traditional type of sources based on the alphabet used in the European area of the Ottoman empire. Although Montenegro is a small geographic area does not fall behind in any other area of the powerful Ottoman in terms of widespread of sources distribution, important for its history. In the Ottomans archives there are close to a hundred million documents and about 365.000 defter (registers)in addition to them, there are also the documents relating to the history of around forty European and North African countries, then several Asian countries that had contacts with the Ottoman empire. This should be also added to the obligations of the provincial Beylerbey and regional qadi who were ordered by ferman from 1536 to record their decisions and actions in defter and to keep them. Documents from Beylerbey archives have not been transferred to the Central Ottoman archive, which means that these documents we should be found in other archival centres ${ }^{17}$.

In perspective, the beginning that rested on enthusiasm should get its own organized and institutionalised characteristic. As soon as, it is estimated there are about 60.000 documents in the Turkish archives referring of Montenegro. Should we highlight that only a small number of these documents is known to the scientific public and in that sense there is a lot of work for generations. It was really important that the "Protocol on cooperation between State Archive of Turkey and State Archive of Montenegro" had been signed on June 22, 2011. On this occasion, we have to agree with the words of the then Ambassador of Turkey in Montenegro, Mrs Emine Birgen, who said: "this is one of the most important agreements signed by Montenegro and Turkey, and it is our duty to pass the history on the next generations accurately, objectively, and equally. The director of the State Archive of Turkey Prof. Dr. Yusuf Sarinay used this opportunity to present to State Archive of Montenegro the berat from 1715 (which contains the appointment of Turkish captain Dizdar), then a letter from King Nikola addressed to the president of Turkey from 1866. (thanking him for tha yacht he received as a gift), a copy of original agreement between two countries from 1910, and a CD catalogue which contains more than 20.509 documents referring to Montenegro, stored in the funds of Turkish archives. In the end, it is worth to point out that the extraordinary cooperation was established between two Ministries of Science as well as numerous protocols of inter-university and academic cooperation, numerous student population from Montenegro at Universities in Turkey (over 250 from 2014.), a safe basis that will result not only in new setting scientific goals but a better and more comprehensive understanding, not only of Montenegro and Turkey, but of Eastern and Western civilisation, no matter what it meant in modern intellectual circles. All of the above can be a sufficient basis for a comprehensive and systematic study of this type of historical sources and therefore satisfying the principles of modern science in historiography. The Edition of CANU is the first such project in the history of Montenegro, designed to be expanded, refined or changed in searching for new knowledge. The first three volumes of the edition contain the published and translated sources of Ottoman provenance to date. There are sources that have been published and translated into our language referring to the present territory of Montenegro. A difficult problem was to order the documents chronologically, having in mind the design of the complete edition. Practically, it is impossible to follow the principle of dating from the beginning to the end, due to the different types of sources being published, so this issue will be addressed while on the move, taking care not to undermine the basic principles of determination of history. Thus in the first volume of the edition there were sources from the beginning of 15th century to 1571.; in the second volume (1571-1683); in the third volume (1683-1913). From the above, it is noticeable that the chronological guidelines

17 See Onder Bayir, "Važnost Osmanskih Arhiva s Aspektaproučavanja Rumelije, Anali: Gazi Husrev-Begove Biblioteke, Sarajevo, 2010, 31, 45-64; instance valuable resources such as Pljevaljski sidžil found in the Archives of the Croatian Academy of Sciences and Arts in Zagreb, while according to some sources Podgorički sidžil is located in the State Archives in Tirana.

Near East Historical Review www.nehrreview.com 
relevant for Lepant, Vienna, and Balkan wars are recognized as an acceptable time framework for the understanding of process in The Ottoman Empire and Montenegro.

\section{Conclusion}

In order to ensure the integrity, functionality and usability of the edition for new historical knowledge or the review of existing ones, it is necessary that the published sources are "close" as much as possible to the original. This means, make sure to specify the place where the original is located, preserve the form of dating on the original, and intervene where there is a need for reporting confusion. The accompanying bibliographies of published sources as well as the decision on publishing of the translated register of documents, with the permission of competent Turkish institutions (State Archive of Turkey), which made available to us the catalogue of registry documents, submitted to the DACG, are in the function of obtaining additional information about the sources located in Turkish archives. Comparative search jobs for unpublished documents, then identification of published and translation of collected, but unpublished documents, represent the basis for the edition of several volumes, of which the first volumes will contain published and translated sources important for the history of Montenegro. After that, there will be the publication of unpublished but translated sources, in accordance with the scientific methodology and principles that will be determined in further work on the edition.

\section{Bibliography}

\section{A. Archives}

\section{Directorate of State Archives Ottoman Archives (Devlet Arşivleri Başkanlığı Osmanlı Arşivi (İstanbul) (BOA)}

"Hersek Livası Nahiyelerinin Nüfus Hasılatıyla Tımarlarına Ve Kale Müstahfızlarına Ait Tımarları Havi Mufassal Tahrir Defteri.”, BOA, TT.d., 5, (H-29-12-882)

“İşkodra, İpek ve Podgoriçe Vesair Nahiyelerin Nüfus, Hasilat-I Has, Zeamet Ve Timarlarini Gösterir Mufassal Tahrir Defteri”, BOA, TT.d.,17 (H-29-12-890)

İskenderiye Livasina Tabi Ipek, Büberler, Klemente, Komnin, Dragoz'a Ait Has, Timar Ve Zeametlerinin Icmal Defteri. BOA, TT.d., 26 (H-29-12-902)

"Karadağ Vilayetinin Nüfus Ve Baştinelerini Havi Mufassal Tahrir Defteri”, BOA, TT.d., 106, (H-29-12-927)

"Karadağ Vilayetinin Nufus Ve Hasilat Ve Memlahalariyla Kardağ Kanunnamesini Havi Mufassal Tahrir Defteri.”, BOA, TT.d., 122 (H-29-12-929)

"Karliili, Tırhala, Ağrıboz, Mora, Rodos, İşkodra, Dukakin, Ohri, İlbasan Livaları Mufassal Tahrir Defteri. y.tt", BOA, TT.d., 367, (H-29-12-973)

"Dukakin Livasının Ve Karacadağ Nahiyelerinin Nüfuslarını Ve Haslarını Ve Venedik'e Aid Kotur, Astari Grad, Bar Kaleleri Hududlarını Karacadağ Kanunnamesini Ve Dukakin Livasındaki Tımarları Havi Mufassal Tahrir Defteri”, BOA, TT.d., 499 (H-29-12-978)

"İskenderiye Livası Kanunnamesiyle İskenderiye Livası Köylerinin Nüfus Ve Hasılatıyla Tımar Ve Evkafinı Havi Mufassal Tahrir Defteri.”, BOA, TT.d., 500 (H-29-12-978)

\section{Tapu ve Kadastro Genel Müdürlüğü Kuyûd-ı Kadîme Arşivi (TKA)}


T.K.A. No.63, 1591 ,

\section{B. Literature}

Bayir, Onder, "Važnost Osmanskih Arhiva s Aspektaproučavanja Rumelije, Anali: Gazi HusrevBegove Biblioteke, Sarajevo, 2010, 31, 45-64;

Mićić, Srdjan, “О проблемима истраживања југословенских стручних делегација у архивима Беча и Цариграда “, (On Professional Delegations' Research Problems in Vienna and Constantinople Archives), АРХИВ Часопис Архива Југославије (ARCHIVE Journal of the Archives of Yugoslavia), 2012, vol. 1-2, pp. 34-51.

Özcan, Uğur, II. Abdülhamid Dönemi Osmanlı Karadağ Siyasi İlişsileri, Türk Tarih Kurumu (TTK) Ankara 2013.

Temizer, Abidin, "Karadağ' da Osmanlı Hâkimiyetine Dair”, Yeni Türkiye Yeni Türkiye, RumeliBalkanlar Özel Saylst-III, 2015, p.3016-3015.

Temizer, Abidin, "Karadağ'da öteki sorunu: Müslümanlar (1878-1913)", History Studies, Volume 5 Issue 3, May 2013, p. 223-240.

Vujovic, Dimitrije Dimo, "Foreign sources on the history of Montenegro, Sources and historiography about Montenegro", Works from a scientific meeting held in Titograd 1718 December 1990, CANU 13, 1993, p.127-145 